\title{
Problems and Prospects of Weather Index Based Crop Insurance in Developing Countries: A Case for Rural Farmers in Bangladesh
}

\author{
${ }^{1}$ Dr. Md. Mushfiqur Rahman, ${ }^{2}$ Bikash Chandra Ghosh, ${ }^{3}$ Dr. Mir Khaled Iqbal \\ Chowdhury \\ ${ }^{1}$ Associate Professor,Department of Business Administration, Pabna University of Science \& Technology, \\ Pabna-6600, Bangladesh. \\ ${ }^{2}$ Lecturer, Department of Economics, Pabna University of Science \& Technology, Pabna-6600, Bangladesh. \\ ${ }^{3}$ Associate Professor, Department of Economics, Pabna University of Science \& Technology, Pabna-6600, \\ Bangladesh
}

\begin{abstract}
This desk study conceptualizes weather-index based crop insurance as an instrument to graduate poor farmers out of poverty trap. I examine the advantages of this product over traditional crop insurance based on developing countries experience. The author tries to address the problems and challenges in implementing this insurance product in low income countries. Based on literature it addresses some problems and issues in implementing this product in Bangladesh considering context specific issues of this country. The main objective of this paper is to theoretically assess weather-index based crop insurance as an instrument to graduate poor farmers out of poverty trap. This study is a completely desk based one. Data have been collected from literatures of different sources such as journals, working papers, World Bank and other development organizations' websites and research publications those are relevant to the study. Proper preparation for index measurement, premium determination, flexible product design, wider stakeholder involvement, public private partnership, and a 'big push' from government and donors through seed financing can promote weather index based crop insurance in Bangladesh.
\end{abstract}

Key Words: Crop insurance, poverty trap, weather index.

\section{Introduction}

Rural poor people in developing countries are vulnerable to a range of risks and constraints that impede their socio-economic development. Weather risk, in particular, is pervasive in agriculture. Weather shocks can trap farmers and households in poverty, but the risk of shocks also limits the willingness of farmers to invest in measures that might increases their productivity and improve their economic situation. Frequency and magnitude of these weather related calamities have increased in recent years (CCC, 2009) and it disproportionately affect rural poor (Chantarat, 2009) in the form of cyclone, drought, earthquake, torrential rainfall, flood (CCC, 2009), or in the form of extreme changes in temperature. All these perils (shocks) seriously affect agricultural production. These sorts of natural hazards increase vulnerability and exacerbate poverty level of rural farmers working in environmentally vulnerable developing countries.

Bangladesh is one of the environmentally vulnerable countries in South Asia with heterogeneous geographical locations, hydrological influence of monsoon rainfall and regional water flow pattern (Rahman et al. 2007). High propensity to natural disasters such as floods, droughts, torrential rains and cyclones pushes agricultural sector of this country into vulnerable position. Majority of people, who are living in rural areas are poor and agriculture is the main source of their income. The main risk for rural farmers in this country is crop failure due to unexpected variations in weather condition.

Traditional risk management mechanisms like conventional micro-insurance, crop insurance, and other formal methods such as savings, loans, or informal measures like donations, gifts, mutual insurance networks with neighbors, and safety nets are less effective in covering farmers' losses (Park, 2006; Santos et al. 2011; CCC, 2009; Clarke et al. 2012b). The idiosyncratic and covariant weather shocks can hardly be insured and managed by rural poor using any of these mechanisms (Clarke et al. 2012a, 2012b). Weather index based crop insurance is now using as an important risk management tool to overcome vulnerability of rural farmers caused by above mentioned disasters in low income countries. The question is now: can weather index based crop insurance helps to overcome poor farmers' vulnerabilities to their agriculture productions caused by weather related risks in these low income countries? Can it be adaptable for poor farmers in Bangladesh? This paper tries to analyze these issues. Based on the analysis from developing countries perspectives of the world and country 
context information, I tried to identify the problems and prospects of weather-index based crop insurance in Bangladesh. As this issue is new and important for the economic and development perspective of the agro-based economy of Bangladesh, this study hopes to contribute significantly in the economic literature, policy makers and practitioners. This has imbued the researcher to conduct the research entitled, "Problems and Prospects of Weather Index Based Crop Insurance in Developing Countries: A Case for Rural Farmers in Bangladesh."

\subsection{Objectives of the study}

The main objective of this paper is to theoretically assess weather-index based crop insurance as an instrument to graduate poor farmers out of poverty trap. In addition that the study has some specific objectives which are as follows:

i) to identify the problems and prospects of weather-index based crop insurance in developing countries of the world as well as in Bangladesh.

ii) to evaluate the viability of weather-index based crop insurance in Bangladesh in particular and low income countries of the world in general.

iii) to find out the problems in its implementation in Bangladesh.

iv) to suggest some modest remedial measures to overcome the problems prevailing in Bangladesh regarding weather-index based crop insurance.

\subsection{Methodology of the Study}

This study is completely explanatory in nature. Secondary data have been used for conducting the research. Data have been collected from available literatures of different sources such as journals, working papers, World Bank and other development organizations' websites and research publications those are relevant to the objectives of the study.

\subsection{Organization of the Study}

This paper is divided into six sections. Section-1 has presented introduction of the study that includes concepts of weather-index based crop insurance and background of it. Statements of the problem, importance, justification and rationality of the study have been presented here also. Objectives, Methodology and organization of the study have been presented separately in this section. Section-2 discusses agricultural shocks, their linkage with poverty trap and failure of traditional risk management mechanisms in addressing it. In section-3 weather-index based crop insurance contract, its advantages and experiences in developing countries have been described. Section-4 focuses the present status of weather-index based crop insurance in Bangladesh, few literatures on its feasibility study and problems in its implementation in low income countries in general and in Bangladesh in particular. In section-5 some issues for its implementation in Bangladesh have been produced and finally section- 6 concludes the study.

\section{Poverty Trap and Traditional Agricultural Insurance}

This section analyzes the poverty trap in rural agricultural farmers, impact of shocks in agriculture on poverty and traditional insurance and other mechanisms to address these shocks.

\subsection{Shocks in Agriculture and Chronic Poverty Trap}

Majority of rural poor households in developing countries who depend on traditional rain-fed agricultural economies, variations in weather conditions put them into substantial risks (Molini et al. 2008; Skees, 2008a). The main risk for them is crop failure due to unexpected variation in weather in the form of changes in rainfall pattern, prolonged drought or devastating flood, salinity intrusion from sea level rise, frequent cyclone, increase of temperature and irregular monsoon. Climate change in recent years alters and causes all these augmenting irregularities and yield variations in agricultural production. There is no mechanism in place in many low income countries to protect their large losses from extreme weather events and so their income and economic activities are likely to be worsened (Skees, 2008a). With few assets in the hands of these poor households, the high uninsured risk exposure caused by unexpected weather events trap them into chronic poverty (Barnett et al. 2008) when they do not have other external financial support.

According to Dercon (2004), poverty and vulnerability is interlinked. His study in rural households in Ethiopia finds that most of the households (78\%) are suffered seriously due to harvest failure brought on by droughts, floods, frosts or pests, and $40 \%$ suffered due to illness and death of both family members and livestock. Collins et al. (2009) also finds similar result from small sample of poor and 'near poor' household survey in India, Bangladesh and South Africa. Carter et al. (2005) finds that extreme weather events cause severness to rain-fed agriculture and destroy economic well being that cause fall in current income quickly and push rural small households into poverty trap. It is beyond the control of rural poor farmers to recover potential 
loss by some low risk activities like crop diversification, or supplementary off-farm activities (Anderson, 2002; Dercon, 2004; Carter et al. 2005; Skees, 2008a).

Moreover, new start up, improvement and intensification associated with high return strategies are not possible for them using their limited resources (Skees, 2008a). Limited household assets can overcome mild shocks such as illness or mild economic downturn (Dercon, 1996), but in case of severe and widespread shocks, everyone in the community fall into the same position, try to sell their valuables in market, and it causes to fall in prices of their assets (Skees, 2008a). Moreover, these goods are susceptible to weather risks. So, once the asset position of households fall below the poverty line, it is not possible to recover and regain its previous economic position and these vulnerable people ultimately fall into poverty trap (Barnett et al. 2008; Skees, 2008a).

Dercon and Hoddinott (2005) study in Ethiopia and Zimbabwe find that this temporary set-back turn into permanent deprivation to the poor, it has long term consequence by diminishing their future employment prospects and productivity when their children loss the hope of their career development from stature and schooling. Finally "the impact of these transitory shocks may well be felt for several generations" (Dercon and Hoddinott, 2005; p. 134). The study of Carter et al. (2005), Caretr and Barrett (2006), Dercon (1998, 2005), Krishna (2006), Mc Peak and Barrett (2001), Santos and Barrett (2006), and Barnett et al. (2008) imply that all the shocks push people below threshold, put them downward spiral into destitution, and these poor people always try to climb out of the trap.

\section{2. Failure of Traditional Crop Insurance and Other Informal Mechanisms}

As we mentioned in previous sub-section, alternative informal strategies to overcome risks of poor farmers almost failed. No formal or informal financial institutions try to extend credit to them. However, microinsurance facilities form traditional insurance companies in these markets is undersupplied in some countries or failed due to strong covariate risk exposure, information asymmetry problem, high transaction costs, lack of effective legal system to enforce insurance contracts and inadequacy of infrastructure and logistics (Barnett, Barrett and Skees, 2008). Premium determination may be inadequate, and moral hazard (engaging forbidden or high risky activities) may result in higher claim (Barnett et al. 2008; Skees, 2008a). These problems increase monitoring cost in developing countries (Chambers, 1989; Coble et al. 1997; Skees and Reed, 1986; Barnett et al. 2008).

Transaction costs of offering micro-insurance in rural areas is higher than in urban areas due to small amount of premium, limited number of policy holders, requirement of sales agent and high transportation costs (Binswanger and Rosenzweing, 1986). This cost is high in crop insurance as it requires frequent assessment of crop losses (Barnett et al. 2008), and is subject to administrative difficulties (Skees, 2008a). In case of multiple peril crop insurance, peril covers a 'set of events' in which loss assessment for every peril is difficult (Skees, 2008); underwriters need exact and accurate information to reduce adverse selection and moral hazard problem along with monitoring and administrative costs (Hazell, 1992; Skees and Barnett, 1999). Premium paid by the farmers for multiple peril crop insurance does not cover costs of delivery and underwriting the peril and require state subsidies even in United States and Canada (Skees, 2008a). So in developing countries, it is expensive for the traditional insurance providers to offer crop insurance facilities due to these problems and require a new set of insurance coverage. Weather index based crop insurance is the one that can overcome these limitations if it applies by considering country context, weather conditions and other infrastructures are necessary to implement it.

\section{Weather Index Based Insurance as a Risk Management Technique}

Against above mentioned backdrops of traditional crop insurance, index based insurance is a new risk management instrument in developing and low income countries although it is an old mechanism in developed countries.

\section{1. What is Weather Index Based Crop Insurance?}

In index based insurance contract, chosen index correlates to loss and there is no adjustment cost, moral hazard and information asymmetry problem (de Janvry and Sadoulet, 2011). The distinguishing feature of index insurance is that "payment of indemnity is based on value obtained from an index that serves as a proxy for losses rather than upon the individual losses of each policy holder" (Skees, 2008a; p. 7). Indemnity in this case is based on value obtained from an index that serves as a proxy for losses rather than individual losses of each policyholder (Skees, 2008a). In this contract, payment is "based on the realization of an underlying index relative to a pre-specified threshold" (Barnett et al. 2008; p. 1772). Payment begins if such point triggers out irrespective of the extent of actual loss (Skees, 2008a). The underlying index is easily and objectively measurable, transparent and based on random variables (Barnett et al. 2008). 
Weather-index based crop insurance contract is a contingent claim contract for which payment is based on specific objective weather parameter that is closely correlated with farm level yields or revenue outcomes (Manuamorn, 2005; Barnett et al, 2008). It protects farmers against crop losses as the index or threshold is highly correlated with crop yields (Barnett et al, 2008; Miranda, 1991; Barnett et al, 1997). Some of the weather indices used in agriculture insurance are cumulative rainfall index, cumulative temperature or soil moisture index, livestock mortality index, satellite imagery index, and droughts index (Deng et al. 2007; Mahul, 2001; Turvery, 2001; Barnett et al. 2008).

Index based insurance needs to best suite with agricultural production in areas where rural farmers face widespread crop losses caused by weather related perils (Manuamorn, 2005). The events triggered must be easily measurable like rainfall below or above certain level in certain days of the year, occurrence of frost on the number of days or hours in a day on average, the temperature in the form of heat or cold depending on the type of crop (Alderman and Haque, 2007). Moreover, there must be time series data set with an accurate statistical probability (Barnett, Barrett and Skees, 2008) to form an index that is "easily measured, objective, transparent, independently verifiable and available in a timely manner" (Alderman and Haque, 2007; p. 5). It can then minimize risks, increase confidence among market participants and farmers when it is protected from human manipulation (Alderman and Haque, 2007; Manuamorn, 2005; Hazel and Skees, 2006). Moreover, it must be timely reported by an objective third party (Barnett et al, 2008) and the variable must be stable and sustainable over time (Manuamorn, 2005).

\section{2. Experience of Weather Index Based Crop Insurance in Developing Countries}

The example of first commercial weather-index based agricultural insurance in developing countries is in India. ICICI Lambard is a general insurance company that first offered this product through a microfinance organization, BASIX at Andhra Pradesh. Since 2003, it is selling weather-index based insurance products to farmers to protect them from insufficient rainfall during sowing and kharif (at crop growth phase), and from excessive rainfall at harvest phase to cover losses (Gine et al. 2007; Barnett et al, 2006). It is now working as a commercially viable insurance product in seven states of India (Manuamorn, 2007; Alderman and Haque, 2007; Barnett and Mauhal, 2007; Lilleor et al. 2005).

Another example is FONDEN/FAPRACC in Mexico that started its operation in 1995 by government for relief and reconstruction with productive safety nets. FAPRACC piloted weather-index insurance product in 2002 based on probability of droughts using information from local weather stations. In 2004 it hired reinsurance coverage and in 2005 it paid first claim of $\$ 10.5$ million due to the trigger up of drought index. The payment of indemnity was $16 \%$ of full value coverage. Government supported part of the program expenditure as part of their safety net program (Alderman and Haque, 2007).

Till to date, weather-index based crop insurance is applying in many developing countries around the world. In 2007, GIIF (Global Index Insurance Facility) was launched by signing agreement between European commission and ACP (Africa, Caribbean and Pacific States) secretariat to provide weather index insurance facilities to agricultural farmers in ACP countries (GIIF Fact sheet available at: www.ifc.org/GIIF). Till to August 2012, it provided insurance facilities to around 100,000 farmers in nine countries (GIIF Newsletter, August-September, 2012). An initial fund of 24.5 million euro is supplied by the European Commission, \$ 2 million by Japan Government and $\$ 0.5$ million by Dutch Ministry of Foreign Affairs (GIIF Newsletter, April, 2012; May-June, 2012; GIIF Fact sheet available at: www.ifc.org/GIIF).

However, all the insurance programs in developing countries are still at infant stage or at developing stage except that in India. At this stage, it is not easy to justify the impact, sustainability and market depth of this program. A brief scenario of this program in some developing countries is presented here with small empirics.

Table 1: Status of Weather Index Based Crop Insurance in Developing Countries

\begin{tabular}{|c|c|c|c|c|c|}
\hline Country & Risk Event & Contract Structure & Index Insurance & Target User & Status \\
\hline China & $\begin{array}{c}\text { Weather related } \\
\text { variables }\end{array}$ & Index insurance & $\begin{array}{c}\text { Different weather } \\
\text { variables }\end{array}$ & $\begin{array}{l}\text { Rice production } \\
\text { farmers }\end{array}$ & $\begin{array}{c}\text { Pilot study in } 9 \\
\text { villages of Zhejiang } \\
\text { prov. }\end{array}$ \\
\hline Ethiopia & Drought & Index insurance & Rainfall & $\begin{array}{c}\text { World Food } \\
\text { Program in Ethiopia }\end{array}$ & $\begin{array}{c}\text { In } 2006, \text { at cost of } \\
\$ 0.93 \text { million for } \\
\text { max. Payout of } \$ \\
7.6 \text { mil. }\end{array}$ \\
\hline Honduras & Drought & & Rainfall & Smallholder farmers & $\begin{array}{l}\text { Pilot project started } \\
\text { in } 2003\end{array}$ \\
\hline India & $\begin{array}{c}\text { Flood, Rainfall \& } \\
\text { Drought }\end{array}$ & $\begin{array}{l}\text { Index insurance } \\
\text { linked to lending } \\
\text { and direct to } \\
\text { farmers }\end{array}$ & Rainfall & $\begin{array}{l}\text { Smallholder farmers } \\
\text { and households }\end{array}$ & $\begin{array}{c}\text { Successfully \& } \\
\text { commercially } \\
\text { operating. In 2011: } \\
9,278,000 \text { farmers } \\
\text { with sum insured \$ } \\
3,174 \mathrm{~m} \text {. claim \$ } \\
125 \mathrm{~m} .\end{array}$ \\
\hline
\end{tabular}


Problems and Prospects of Weather Index Based Crop Insurance in Developing Countries: A Case

\begin{tabular}{|c|c|c|c|c|c|}
\hline Kazakhstan & Drought & $\begin{array}{l}\text { Index for multiple } \\
\text { peril crop }\end{array}$ & Rainfall & $\begin{array}{l}\text { Medium \& large } \\
\text { farmers }\end{array}$ & $\begin{array}{c}\text { Insurance } \\
\text { development }\end{array}$ \\
\hline Malawi & Drought & $\begin{array}{l}\text { Index insurance } \\
\text { linked to lending }\end{array}$ & Rainfall & $\begin{array}{l}\text { Groundnut farmers } \\
\text { of National } \\
\text { Smallholder } \\
\text { Farmer's } \\
\text { Association of } \\
\text { Malawi } \\
\end{array}$ & $\begin{array}{l}\text { Pilot project started } \\
\text { in } 2005 . \text { In } 2008, \\
2600 \text { farmers } \\
\text { brought policies } \\
\text { worth } \$ 2.5 \text { million. }\end{array}$ \\
\hline Mexico & $\begin{array}{l}\text { Drought, natural } \\
\text { disaster for small } \\
\text { farmers }\end{array}$ & Index insurance & $\begin{array}{l}\text { Rainfall, wind speed } \\
\text { \& temperature }\end{array}$ & $\begin{array}{c}\text { State govt. for } \\
\text { disaster and relief } \\
\text { support, FONDEN } \\
\text { program. }\end{array}$ & $\begin{array}{l}\text { Began in } 2001 \text { in } 26 \\
\text { states. In } 2006 \text { it } \\
\text { covered } 28 \% \text { of dry } \\
\text { land and crop land. }\end{array}$ \\
\hline Maxico & $\begin{array}{c}\text { Inefficient irrigation } \\
\text { supply }\end{array}$ & Index insurance & Reservoir levels & $\begin{array}{l}\text { Water user groups } \\
\text { in Rio Mayo area. }\end{array}$ & Proposed \\
\hline Morocco & Drought & & Rainfall & & $\begin{array}{c}\text { No interest from } \\
\text { market participants. }\end{array}$ \\
\hline Nicaragua & $\begin{array}{c}\text { Drought \& } \\
\text { excessive rain in } \\
\text { prod. season }\end{array}$ & Index insurance & Rainfall & Groundnut farmers & $\begin{array}{l}\text { Launched in } 2006 \text { in } \\
3 \text { Departments. }\end{array}$ \\
\hline Peru & $\begin{array}{l}\text { Flood, torrential } \\
\text { rainfall from El- } \\
\text { Nino }\end{array}$ & Index insurance & Rainfall & $\begin{array}{l}\text { Rural financial } \\
\text { institutions }\end{array}$ & Proposed \\
\hline Senegal & Drought & $\begin{array}{c}\text { Index ins. Linked to } \\
\text { yield }\end{array}$ & $\begin{array}{c}\text { Rainfall \& crop } \\
\text { yield }\end{array}$ & Smallholder farmers & Proposed \\
\hline Sri Lanka & $\begin{array}{l}\text { Torrential rainfall, } \\
\text { flood }\end{array}$ & $\begin{array}{c}\text { Index ins. Linked to } \\
\text { cooperatives }\end{array}$ & Rainfall & $\begin{array}{l}\text { Farmers for } 4 \\
\text { season crops }\end{array}$ & $\begin{array}{c}\text { Phase II: } 3337 \\
\text { policies sold in } \\
\text { 2011-12 with Rs } 1 \\
\text { million }\end{array}$ \\
\hline Tanzania & Drought & $\begin{array}{l}\text { Index ins. linked to } \\
\text { lending }\end{array}$ & Rainfall & $\begin{array}{l}\text { Smallholder maize } \\
\text { farmers }\end{array}$ & $\begin{array}{c}24,000 \text { farmers \& } \$ \\
14.7 \text { million } \\
\text { premium in } 2011 .\end{array}$ \\
\hline Thailand & Flood & $\begin{array}{l}\text { Index ins. linked to } \\
\text { lending }\end{array}$ & Rainfall & Smallholder farmers & $\begin{array}{l}\text { Pilot implemented } \\
\text { in } 2007\end{array}$ \\
\hline Ukraine & Drought & Index insurance & Rainfall & Large farms & $\begin{array}{l}\text { Pilot launched in } \\
\text { 2005, discontinued } \\
\text { for limited sales }\end{array}$ \\
\hline Vietnam & $\begin{array}{c}\text { Flood during rice } \\
\text { harvest }\end{array}$ & $\begin{array}{l}\text { Index ins. with } \\
\text { lending }\end{array}$ & River level & $\begin{array}{l}\text { Smallholders rice } \\
\text { farmers }\end{array}$ & In development \\
\hline
\end{tabular}

Sources: Skees (2008b), Barnett et al. (2006 \& 2008), Chen (2011), Clarke et al. (2012a \& 2012b), GIIF

Newsletter (April, 2012); www.gfdrr.org/drfi.

\section{3. Advantages of Weather Index Based Crop Insurance}

Weather index based insurance products have a number of advantages over traditional

crop insurance products especially in case of information asymmetry, moral hazard, administrative costs and standardization problems that are faced in traditional crop insurance (Alderman and Haque, 2007; Manuamorn, 2005; Barnett et al. 2008; Skees, 2008a; Rao, 2011). In low income countries, it is very simple and relatively low costly to administer (Skees, 2008a).

Overcome adverse selection problem: Adverse selection problem caused by asymmetric information can be reduced by introducing weather index based crop insurance because of its typical features of product design, local knowledge, especially when the policyholders' behavior and information are not important in determining risk level (Alderman and Haque, 2007; Manuamorn, 2005; Gine et al. 2008; Skees, 2008a).

Reduce monitoring cost: Due to the advent of efficient product design, the industry does not depend on individual's actual losses (Skees, 2008a). So it is not possible for the individual to change or affect the probability of adverse event. It reduces ex-post and ex-ante moral hazard, and thereby reduces insurer's monitoring cost (Alderman and Haque, 2007; Manuamorn, 2005; Skees, 2008a).

No loss adjustment: Traditional micro-insurance requires high cost in determining which individuals or households suffered from loss, what is the extent of actual loss. But in rural areas, especially in case of agriculture, it is very costly and time consuming to determine the amount of loss and indemnity. However, index based insurance contract does not need to conduct assessment survey to determine indemnities (Skees, 2008a).

Standardized and transparent: Index based insurance contract follows standardized and simple format. For each policyholder, contract needs not be tailored, and this uniformity reduces administrative cost (Skees, 2008a; Manuamorn, 2005). Contrary to traditional insurance, insured can easily understand index insurance (Skees, 2008a).

Reinsurance function: Due to dependency on natural conditions, loss may increase by increasing correlated weather risks; reinsurance facility can cover potential large financial losses. Moreover, moral hazard 
problem reduced in index insurance. So it is easier to transfer risk through re-insurance (Skees, 2008a; Manuamorn, 2005).

\section{Present Status of Weather Index Based Crop Insurance in Bangladesh}

Bangladesh is an agriculture oriented natural disaster prone country in South Asia with heterogeneous geographical locations, monsoon rainfall, and regional water flow pattern (Rahman et al. 2007). Southern part of the country is coastal zone that suffers from salinity intrusion; northern side suffers from drought and northeastern and middle part suffers from flood flow and torrential rain. Rural agricultural contributes $20 \%$ to GDP (MOF, 2012). The country is considered as highly vulnerable due to hardest hit by climate change (Akter, 2012).

The experience of micro-insurance in Bangladesh is in infant stage. Still not any index based insurance product is available in this country. Three commercial insurance companies, one state owned insurer and nine MFIs are providing traditional micro insurance. Only Grammen Fisheries and Padakhep are the two microfinance institutions (MFIs) that are offering livestock insurance. In 1977, the state insurance company, Sadharan Bima Corporation (SBC) started traditional crop insurance to farmers; but the program abandoned in 1996 due to inefficient modeling, non-alignment with agricultural development policy, inadequate preparation and training, too many peril coverage, uniform premium for all coverage, unrealistic indemnity determination and lack of proper monitoring (CCC, 2009).

\section{1. Literature on Index Insurance Feasibility in Bangladesh}

Literature on feasibility of index based insurance product in Bangladesh is very acute. The study of Clarke et al. (2012a) is on the feasibility of index based insurance from demand side and finds that, farmers want to buy an insurance product that will cover the risks they primarily face. The study finds that yield based index insurance that covers weather events is preferable to farmers along with group savings and endowment insurance.

French and Silver (2007) study is on viability of crop insurance to mitigate loss from floods and finds that the program is financially viable if it apply full service model with NGO/MFI participation by offering more affordable weather index based crop insurance products.

However, Akter et al. (2009) finds that partner agent model is marginally commercially viable in riverine floodplain areas for potential crop insurance; but in wetland basin and coastal areas its expected insurance premium exceeds expected indemnity payable to farmers due to nature of disaster risks.

Study of Alam et al. (2011) on the demand for weather index based crop insurance in coastal areas finds that $63 \%$ of the farmers want to pay $\$ 2$ premium which is around $3 \%$ of their monthly income. The study suggests both full service model and partner agent model with NGO participation in the program. The main driving factors behind demand for weather index based crop insurance are vulnerability to cyclone, economic status, education, and awareness by media. However, aid dependency has negative impact on willingness to pay premium.

The most elaborate but theoretical study is by CCC (2009) that is based on the experiences in some other low income countries. The study was conducted by Department of Environment of Bangladesh Government. It mentions causes of failure of traditional micro-insurance in agriculture. It proposes a pro-forma weather index based crop insurance model for farmers considering three major meteorological and geo-physical characteristics of the country: flood, drought and cyclone. It also addresses some of the issues related to implementation of weather index based crop insurance.

\section{2. Limitations in Implementation of Weather Index Based Crop Insurance in Bangladesh}

Some of the limitations in implementation of weather-index based crop insurance are related to the product design itself, some are common problems experiencing in other developing countries where it is started and the others are specific to Bangladesh.

\section{2. 1. Limitations from Product Design Itself}

Covariate and basis risk: This risk is the chance that indemnity payment to the policy holder does not match with the loss the policyholder suffers (Skees, 2008a). It can come in different ways, for example, the insured suffered a loss but not received any indemnity or adequate indemnity for the loss. Also, there is possibility for an insured to receive an indemnity who has not experienced a loss (Alderman and Haque, 2007; Skees, 2008a). The frequency of occurrence depends on the extent of correlation of insured loss with index. But general condition in index insurance is that index insurance works very well when the co-variance between individual farmers and aggregate of individual farmers is high (Rao, 2011).

Reliability and accuracy of data: An essential pre-condition for index insurance is objective and accurate data for measuring index. In some developing countries, there is lack of adequate weather stations using sophisticated technology with reliable and updated equipments (like GPS facilities) to measure weather 
condition, and the stations are sparsely dispersed. Index measurement may not cover all the areas due to geographic and weather based heterogeneities. The data need to be publicly available, accurate, must be free from tempering and is handled confidently (Skees, 2008a).

Precise and accurate actuarial modeling: Insurers must need to understand actuarial properties of underlying index. Proper data record, availability and monitoring it, and expert use of it to develop actuarial model can ensure increased application of index insurance (Manuamorn, 2005; Alderman and Haque, 2007).

\section{2. 2. Problems Common for the Developing Countries}

Weather cycle: Weather index insurance is completely dependent on weather conditions. But weather cycle in every year does not go to the same direction as per hundred year's historical trend to trigger up of an unexpected event like El-Nino or earthquake. Actuarial soundness in this case could be undermined by unexpected weather cycle that may change the probability of insured events (Manuamorn, 2005).

Product familiarity and education: Rural farmers are the potential policy holders of index insurance who do not have previous experience with insurance. For wider acceptance of this product, some sort of education is necessary to understand insurance policy so that they can agree to buy it (Alderman and Haque, 2007). Local insurers and government regulators or policy making entities also require some ideas to know how it management risk (Skees, 2008), and in facilitating and regulating the market. Also it will help insurers in marketing the product (Alderman and Haque, 2007; Manuamorn, 2005).

Financing large losses: In weather index based insurance, potential losses may occur in a large scale when the index triggers. If this happens, insurers have to pay to all policy holders at a time rather than payment to individual that requires large sum of money to pay indemnity. In developing countries, local insurance companies typically do not have sufficient financial resources to cover the losses happened from insured events without presence of re-insurance facilities (Skees, 2008). They need either government or international development organizations support, or re-insurance facilities (Skees, 2008a; Alderman and Haque, 2007).

\section{2. 3. Problems Specific for Bangladesh}

Heterogeneity of farm land and local risk variations: To ensure data accuracy, transparency and quick claim settlement, feasibility study is essential before implementing index insurance (Rao, 2011; Skees et al. 2006; Skees, 2008a). But data availability and reliability is inadequate in Bangladesh. Farm lands in Bangladesh are divided into small pieces; it creates local variation of risks and cause improper premium determination and indemnity estimation. Index based insurance requires high administrative cost in dividing and detailed area classification and gathering information for better index estimation.

Heterogeneity of climatic conditions: In Bangladesh, heterogeneity of different climatic attributes is high. Crop yield varies due to not only rainfall but also to a combination of several other climatic factors like temperature variation, water availability, ground water level, humidity etc (CCC, 2009). Simply rainfall coverage may not be sufficient for the farmers to overcome risk of loss. But, it is almost impossible to cover all the perils related to heterogeneous weather conditions by single peril weather insurance.

Limited insurance capacity: There is lack of infrastructure and absence of expertise in present insurers for effective launching this product. Moreover, it requires various stakeholders' participation like Department of Agriculture, Department of Environment, Banking and Insurance Regulatory Authority, and Local Government \& Engineering Department (LGED) for its effective implementation (CCC, 2009; Akter, 2012). As is available in India, in Bangladesh, there is not any regulatory requirement for commercial or state insurance providers to introduce ago-based insurance.

State and external support: International experience, except that of India, implies that weather index based insurance is not sustainable without state subsidy or international financial and technical help. The expost, ad- hoc model cannot sustain in disaster prone countries as it needs huge investment at initial stage for product development, infrastructure support and for historical data management.

\section{Way Forward: What is Important?}

Despite few limitations and negative findings, some studies finds positive results in introduction of weather-index based crop insurance in Bangladesh. Overcoming limitations and successful implementation of this program in these vulnerable geo-heterogeneous areas are necessary at this stage if we want positive result.

Preparation for effective determination of premium and index: As we mentioned, failure of previous micro- insurance is due to uniform premium. In index based insurance, premium and index determination is on the basis homogeneous unit area. Detailed classification of and into heterogeneous climatic and topographical unit by using land elevation map, rainfall, flood, and salinity intrusion in the areas is important at this stage (CCC, 2009). Also it needs detailed and good quality historical hydro-climatic and weather data.

Less number of perils and multi-peril provision: It is almost impossible to cover all the perils in weather-index based insurance. Different climatic attributes push index insurance vulnerable to high losses. 
Instead, there may be provision to cover 2 or 3 perils by differentiating premium. This can helps in reducing cost of product offering (Clarke et al, 2012a; CCC, 2009). Crop yield varies due to not only rainfall but also combination of several other climatic factors (CCC, 2009). Simply rainfall coverage may not be sufficient for farmers to overcome the risk of losses.

Risk layering option: It may be difficult and costly, but it is important to apply different layers of risk exposures especially in low income countries (Barnett, Barrett and Skees, 2008; Alderman and Haque, 2007). This typical form of risk layering may help farmer in retaining "smaller shortfall of rain and to transfer some risks to commercial providers for greater shortfalls" (Alderman and Haque, 2007: 6). Government or international reinsurance organizations' support can help to address market failure from extreme layer through premium subsidies or reinsurance facilities (Alderman and Haque, 2007; Barnett et al. 2008).

Varying weather index: Instead of applying fuzzy approach to define one index value of climatic attribute, it is better to define varying index for example, $25 \%, 50 \%$ or $75 \%$ below the average level (CCC, 2009). However, it needs proper simulation and probability adjustment considering magnitude and duration of perils and the level of vulnerability before finally applying it.

Wider stakeholder involvement and public private partnership: Literature suggest that implementation of weather-index based crop insurance is associated with not only insurers responsibility, other stakeholders such as hydro-meteorological organization, regulators and involvement of various relevant governmental offices are essential (CCC, 2009; Akter, 2012). Rather than public-private partnership, private sector insurance companies alone are not sufficient. Moreover, the formation of farmers' cooperative within the homogeneous unit area in the community by introducing risk pooling among farmers can overcome local variation of risks, help in educating farmers to understand the product (Hans and Binswanger-Mkhize, 2012).

Wider coverage: At the initial stage, farmers may not want to buy the product. Government can make it mandatory in obtaining agricultural loan, loan from MFIs, or in buying agricultural equipments like fertilizer, seeds, insecticides etc. This will help in ensuring economies of scale, and reducing premium level and help in wider participation.

National and international support and re-insurance: Neighboring India is the example where state owned General Insurance Company (GIC) acts as re-insurer and all commercial insurance companies must have to cede $20 \%$ of their business. National insurance company Sadharan Bima Corporation (SBC) can work as reinsurer. In other developing countries, insurers get subsidy in the form of financial and technical assistance, capacity building, effective implementation and re-insurance coverage. Moreover, it is possible to use a portion of government budget as social safety net program to subsidize premium (Hans and Binswanger-Mkhize, 2012; Akter, 2012).

Partner-agent model or full service model: The study of Akter et al. (2007 \& 2009) argues for partner agent model. Study of French and Silver (2007) argues for full service model. For greater access, studies of Akter (2012), Clarke et al. (2012a) and CCC (2009) support greater involvement of NGO/MFIs, banks, insurance companies and farmers cooperatives. A new inclusion in this process is involvement of mobile phone operators in collecting premiums, as happens in Kenya. It can replace agents' cost of premium collection just with small commission for mobile operators.

\section{Conclusions}

This study conceptualizes weather-index based crop insurance, its application as an instrument to graduate poor farmers out of poverty trap, and examines viability of this insurance product in low income countries in general and in Bangladesh in particular as this program has not yet started in Bangladesh. This study also tries to find out the problems and challenges associated with implementation of weather-index based crop insurance products in Bangladesh.

Weather-index based crop insurance is not the 'one size fit for all' solution, but it tries to address causes of failure of traditional crop insurance for addressing it in index insurance, especially adverse selection and moral hazard problems, cost of monitoring, cost of administering and cost related to indemnity determination and standardization (Alderman and Haque, 2007; Manuamorn, 2005; Barnett et al. 2008; Skees, 2008a; Rao, 2011). Most important issues in implementing weather-index based crop insurance are: how successfully insurance companies are able to manage covariate and basis risks and manage reliable and adequate data. Some studies reveal that weather-index based insurance in developing countries is facing problem of unpredictable weather cycle, heterogeneity of climatic risks, unfamiliarity and lack of proper knowledge. Insurance companies in these countries are not financially well equipped to cover large financial losses when the index trigger.

Based on developing countries experience and considering the issues specific to Bangladesh, some issues are important to address: proper preparation for index measurement and premium determination, flexible product design using less number of perils and multi peril options and different risk layering. Wider stakeholder 
involvement, reinsurance facilities from national and international level with technical support and wider area coverage may increase its viability. Also it needs proper feasibility study and research.

Experimentally launching the product, considering country context, ensuring demonstration effect through public private partnership, and a 'big push' from government and donors through seed financing may promote weather-index based crop insurance in Bangladesh. Proper campaign and awareness creation through government sponsorship can be an effective strategy as is done in Colombia and Philippines for traditional micro-insurance. Implementation of this type of insurance is not an over all rosy picture, it requires time. The journey may be like the 'race of tortoise', where we hope, success may be after a decade, if the journey starts right now.

\section{References}

[1] Akter, S., The Role of Micro-insurance as a Safety Net against Environmental Risks in Bangladesh. The Journal of Environment Development, (June) 21 (2), 2012, 263-280.

[2] Akter, S, R. Brouwer, S. Chowdhury, and S. Aziz, Introducing a Micro-flood Insurance in Bangladesh: Institutional Design and Commercial Viability. PREM Working Paper 07/08, Poverty reduction and Environmental Management, (Amsterdam: Vrije Universitait, 2007).

[3] Akter, S., R. Brouwer, S. Chowdhury and S. Aziz, Is there a Commercially Viable Market for Crop Insurance in Rural Bangladesh? Mitigation Adaptation Strategies and Global Change, 14, 2009, 215-229.

[4] Alam, M. J., M. Nazneen \& F. S. Chowdhury, Demand for Weather Index Based Micro Insurance in Coastal Areas of Bangladesh. Available at: http://www.webmeets.com/files/papers/EAERE/2011/491/Demand\%20for\%20Weather\%20Index\%20B ased\%20Micro-Insurance.pdf (accessed at: 20. 12. 2012), 2011.

[5] Alderman, H. and T. Haque, Insurance against Covariate Shocks- the Role of Index Based Insurance in Social protection in Lower Income Countries of Africa. Working Paper 95, (Washington D.C.: World Bank, 2007).

[6] Anderson, J. R, Risk management and Rural Development: A Review. Agriculture and Rural Development (ARD), Department Strategy Background Paper No. 7, (Washington D.C.: World Bank, 2002.)

[7] Barnett, B. J. \& O. Mauhal, Weather Index Insurance for Agriculture and Rural Areas in Lower Income Countries. American Journal of Agricultural Insurance, 89, 2007, 1241-1247.

[8] Barnett, B. J., C. B. Barrett \& J. R. Skees, Poverty traps and index-based risk transfer products. World Development, 36(10), 2008, 1766-1785.

[9] Binswanger, H. P. \& M. R. Rosenzweing, Behavioral and Material Determinants of Production Relations in Agriculture. Journal of Development Studies, 22, 1986, 503-539.

[10] Carter, M. R. \& C. B. Barrett, The economics of poverty traps and persistent poverty: An asset-based approach. The Journal of Development Studies, 42(2), 2006, 178-199.

[11] Carter, M. R,, P. D. Little, T. Magues and W. Negatu, The Long-term Impacts of Short-term Shocks: Poverty Traps and Environmental Disasters in Ethiopia and Honduras. BASIS Brief 28 (May), (Madison: University of Wisconsin, 2005).

[12] CCC. Crop Insurance as a Risk Management Strategy in Bangladesh. Climate Change Cell, Department of Environment, Component 4b, (Government of Peoples' Republic of Bangladesh,Dhaka: CDMP, MoFDM, 2009).

[13] Chambers, R. G., Insurability and Moral Hazard in Agriculture Insurance Markets. American Journal of Agricultural Economics, 71, 1989, 604-616.

[14] Chantarat, S., Pro-poor Risk Management: Essays on the Economics of Index Based Risk Transfer Products. Ph.D Dissertation, (Faculty of Graduate School, Cornell University, 2009)

[15] Chen, Y., Weather Index Based Rice Insurance- A Pilot Study of Nine Villages in Zhenjiang Province, China. Master Thesis at Management, Technology and Economics, (MTEC), (Swiss Institute of Technology Zurich, 2011).

[16] Clarke, C., N. Das, F. de Nicola, R.V. Hill, N. Kumar, and P. Mehta, Value of Customized Insurance for Farmers in Rural Bangladesh. IFPRI Discussion Paper 01202 (August), ( International Food Policy Research Institute, 2012a).

[17] Clarke, D. J., O. Mahul, K. N. Rao and N. Verma, Weather based Crop Insurance in India. Policy Research Working Paper 5985. (Washington DC: World Bank, 2012b).

[18] Coble, K. H., T. O. Knight, R. D. Pope, \& J. R. Williams, An expected-indemnity approach to the measurement of moral hazard in crop insurance. American Journal of Agricultural Economics, 79(1), 1997, 216-226.

[19] Collins, D., J. Morduch, S. Rutherford, and O. Ruthven, Portfolio of the Poor: How the World's Poor Live on \$ 2 a Day. (Princeton: Princeton University Press, 2009)

[20] De Janvry, A. and E. Sadoulet, From Indemnity, Index-based, and to Group Weather Insurance Contracts. Policy Brief Note 25 (July), (Foundation pour let etudes et researches sur le developpement international, France, 2011).

[21] Deng, X., B. J. Barnett, D. V. Vedenov, \& J. W. West, Hedging dairy. Prduction losses using weather-index based insurance. Agricultural Economics, 36(2), 2007, 271-280.

[22] Dercon, S., Risk, Crop Choice and Savings: Evidence from Tanzania. Economic Development and Cultural Change, 44, 1996, 485513.

[23] Dercon, S., Weather Risk and Activity Choice: cattle in Western Tanzania. Journal of Development Economics, 55, 1998, 1-42.

[24] Dercon,S., Growth and Shocks: Evidence from Rural Ethiopia. Journal of Development Economics, 74, 2004, 309-329.

[25] Dercon, S. Ed., Insurance against Poverty, (Oxford: Oxford University Press, 2005).

[26] Dercon, S. and J. Hoddinott, Health Shocks and Poverty Persistence. (Oxford: Oxford University Press, 2004)

[27] Dufhues, T., U. Lemke and I. Fischer, Constraints and Potentials of Livestock Insurance Schemes- A case Study from Vietnam. Discussion Paper No. 05/2004, (Institute of Animal Production in Tropics and Subtropics, and Animal Husbandry and Breeding Section, University of Hohenheim, 2004).

[28] French, L. and E. Silver, Crop Insurance to Mitigate Loss from Flood in Bangladesh- A Viability Assessment. M. Sc. Environment and Resource Management Thesis, (Amsterdam: Vrije Universitait, 2007)

[29] GIIF Expanding Access to Index Based Insurance Facilities in Developing Countries. Global Index Insurance Facilities (GIIF) Newsletter, (Issue-3, August-September), 2012, Available at: http:// www.ifc.org/GIIF.

[30] GIIF, What's New in the Index Insurance Facility. Global Index Insurance Facilities (GIIF) Newsletter, (Issue-2, June-July), 2012, Available at: http:// www.ifc.org/GIIF. 
[31] GIIF, What's New in the Index Insurance Facility. Micro Insurers' Weather Index Insurance Product Pilot in Tanzania. Global Index Insurance Facilities (GIIF) Newsletter, (Issue-1, April), 2012, Available at: http:// www.ifc.org/GIIF.

[32] Gine, X., R. Townsend and J. Vickery, Statistical Analysis of Rainfall Insurance Payouts in Southern India. American Journal of Agricultural Economics, 89, 2007, 1248-1254

[33] Gine, X., R. Townsend, and J. Vickery, Pattern of Rainfall insurance Participation in India. The World Bank Economic Review, 22(3), 2008, 539-566.

[34] Hans, P. and Binswanger-Mkhize, Is There Too Much Hype about Index-based Agricultural Insurance? The Journal of Development Studies, 48(2), 2012, 187-200.

[35] Hazel, P. and J. R. Skees, Insuring Against Bad Weather: Recent Thinking. R. Radhakrishna, S. K. Rao, S. Mahendra Dev, and K. Subbarao (Eds.). India in a globalizing world: Some aspects of macro economy, agriculture and poverty. (New Delhi: Academic Foundation, 2006).

[36] Hazell, P.B.R., The appropriate role of agricultural insurance in developing countries. Journal of International Development, 4, 1992, 567-581. DOI:10.1002/jid.3380040602

[37] Krishna, A., For Reducing Poverty Faster: Target Reasons before People. Working Paper. (Duke University, 2006).

[38] Lilleor, H. B., X. Gine, R. Townsent and J. Vickery, Weather insurance in semi-arid India. The World Bank Working Paper (March 23), (Washington D.C.: World Bank, 2005).

[39] Mahul, O., Optimal insurance against climatic experience. American Journal of Agricultural Economics, 83(3), $2001,593-604$.

[40] Manuamorn, O. P., Scaling up Micro-insurance- the case of Weather Insurance for Smallholders in India. Agricultural and Rural Development, Conference Edition, (Washington D. C.: World Bank, 2005).

[41] Mc Peak, J. G. and C. B. Barrett, Differential Risk Exposure and Stochastic Poverty traps among East African Pastoralists, American Journal of Agricultural Economics, 83, 2001, 674-679.

[42] Mechler, R., J. Linnerooth-Bayer and D. Peppiatt, Microfinance for Natural Disaster in Developing Countries- Benefits, Limitations and Viability, ProVention Consurtium, 2006.

[43] Miranda, M. J., Area Yield Insurance Reconsidered. American Journal of Agricultural Economics, 73, 1991, $233-242$.

[44] MOF, Bangladesh Economic Review, (Ministry of Finance, Government of the Peoples' Republic of Bangladesh, 2012).

[45] Molini, V., M. Keyzer, B. Van Den Boom \& W. Zant, Creating safety nets through semi-parametric index-based insurance: A simulation for Northern Ghana. Agricultural Finance Review, 68(1), 2008, 223-246.

[46] Park, C., Risk Pooling Between Households and Risk Coping Measures in Developing Countries: Evidence from Rural Bangladesh. Economic Development and Cultural Change, 54(2), 2006, 423-457.

[47] Rahman, A. A., M. S. Alam, S. Alam, M. Rabi-Uzzaman, M. Rashid and G. Rabbani, 2007. Risks, Vulnerability and Adaptation in Bangladesh, Human Development Report, (UNDP, 2007).

[48] Rao, K. N., Weather Index Insurance: Is it the Right Model for Providing Insurance to Crops? ASCI Journal of Management, 41(1), 2011, 86-101.

[49] Santos, I., I. Sharif, H. Z. Rahman and H. Zamern, How do Poor Cope with Shocks in Bangladesh? Evidence from Survey Data. Policy Research Working Paper Series 5810, (Washington D. C.: World Bank, 2011).

[50] Santos, P., \& C. Barrett, Heterogeneous wealth dynamics: On the roles of risk and ability. http://dx.doi.org/10.2139/ssrn.998549, 2006.

[51] Skees, J. R., Innovation in Index Insurance for the Poor in Lower Income Countries. Agricultural and Resource Economics Review, 37(10), 2008a, 1-15.

[52] Skees, J. R., Challenges for use of index-based weather insurance in lower income countries. Agricultural Finance Review, 68(1), 2008b, 197-217.

[53] Skees, J. R. and B. J. Barnett, Conceptual and Practical Consideration for Sharing catastrophic/Systematic risks. Review of Agricultural Economics, 21,1999, 424-441.

[54] Skees, J. R. and M. R. Reed, Rate-making and firm level crop insurance: Implications for adverse selection. American Journal of Agricultural Economics, 681986, 653-659.

[55] Skees, J. R., J. R. Black, \& B. J. Barnett, Designing and rating an area yield crop insurance contract. American Journal of Agricultural Economics, 79(2), 1997, 430-438.

[56] Skees, J. R., J. Hartell and J. Hao. Weather Index-based Insurance in Developing Countries: Experiences and Possibilities. In Sarris, A. and Hallam, D. (Eds.). Agricultural Commodity Markets and Trends: New Approaches to Analyzing Market Structure and Instability. Food and Agricultural Organization of the United Nations, (Cheltenham UK and Northampton MA: Edward Elgar Publishing, Ltd., 2006).

[57] Turvery, C. G., Weather Derivatives for Specific Event Risks in Agriculture. Review of Agricultural Economics, 23, 2001 , 333-351. 